\title{
EU efter Merkel
}

\section{Af Peter Wivel}

I 2015 tog Tyskland imod næsten en million asylsøgere. Angela Merkels beslutning om på forhånd at give flygtninge fra Syrien asylstatus udløste et drama og rejste spørgsmålet, om kansleren overlever den politiske krise i Tyskland og i Europa. En nærmere analyse af Merkels egen begrundelse for den store humanitære gestus viser, hvad EU risikerer at måtte mangle, hvis Merkel skulle forlade tysk politik i utide eller ved næste valg til Forbundsdagen i 2017.

EU efter Merkel? Et pessimistisk spørgsmål, der får den krisebevidste iagttager, der stiller det, til at virke mindre naiv, end den tåbe, der ikke stiller det.

Pessimismen er velbegrundet. Tyskland står over for sin største politiske udfordring siden genforeningen i 1990. Samtidig gik Europa ind i 2016 med en stribe uløste konflikter, der angår selve fællesskabets livsnerve. For første gang siden indførelsen af den fælles mønt foreslog en finansminister, oven i købet Tysklands, at et land, in casu Grækenland, temporært forlod eurozonen. Over to omgange og trods megen modstand besluttede statsog regeringschefer fra 25 af EU's 28 medlemslande at fordele i alt 160.000 flygtninge mellem sig. Foreløbig er mindre end
200 af dem blevet fordelt. Schengen, altså de åbne grænser i EU, er tæt på at blive lukket af overivrige nationalstater. Ved regionalvalget i Frankrig fik det EU-fjendtlige Front National omkring 30 pct. af de afgivne stemmer. Et Frexit er rykket nærmere.

Værre kan det dårligt blive, og et EU efter Merkel ville være et EU uden ledelse, og hvad værre er, med alvorlige ridser i sit eget værdigrundlag. Det er perspektivet.

Måske netop derfor, måske netop på grund af denne ophobning af alarmerende krisetegn satte Merkel i 2015 alt på et bræt. Hun rykkede EU's grundværdier i centrum, så i det mindste de ikke gik i glemmebogen. Resultatet blev et drama uden sidestykke i endnu et tysk efterår, der vil gå over i historien. Aldrig har Merkel været udsat for heftigere trommeild. Men som det amerikanske Time Magazine skrev i sin begrundelse for i december at gøre den tyske kansler til årets personlighed': "Ledere prøves, når folk ikke ønsker at følge dem". Det er sandt.

Populister og fjender af fremmede i ind- og udland løb storm mod kansleren. Frauke Petry, formand for Alternativ for Tyskland (AfD), forlagte på partiets stormomsuste kongres i Hannover i november Merkels afgang: "Dét klarer hun!",

Peter Wivel skriver free lance for Politiken fra Berlin. 
råbte Petry med henvisning til Merkels forsikring, "Det klarer vi”, møntet på flygtningekrisen. Dén klarer hun nemlig ikke, hvis det står til Petry og hendes stadigt mere aggressivt indvandrerfjendske og antimuslimske parti. Tyske aviser, selv de mest seriøse, greb anledningen og spekulerede allerede fra september rastløst i nye kanslernavne, mens Merkels opinionstal veg marginalt til fordel for AfD's.

Mere end 200 endnu ikke færdiggjorte eller allerede fungerende flygtningehjem blev overalt i Tyskland udsat for pøbeloptøjer, vold og i mange tilfælde brandstiftelse grænsende til mordbrand. Pegida, en bevægelse af 'patriotiske borgere', frygter, at 'aftenlandene', en sentimental betegnelse for Vesten, bliver islamiseret. Pegida tordnede mandag efter mandag i Dresden i delstaten Sachsen mod indvandrere og muslimer. Ved en enkelt lejlighed rejste deltagere, uden at politiet greb ind, galger reserveret til Merkel og hendes vicekansler, Socialdemokratiets formand Sigmar Gabriel.

\section{Identitetspolitikkens trussel}

Her så Merkel noget, hun ikke brød sig $\mathrm{om}$. Den indre fred i Tyskland var akut truet af en identitetspolitik, der allerede har sat befolkningsgrupper hårdt op mod hinanden i mange andre europæiske lande. I sin nytårstale ved årsskiftet 2014/2015 advarede kansleren sine landsmænd mod at følge dem, der som Pegida kalder til fremmedfjendtlige demonstrationer: "For ofte er der fordomme, for ofte kulde, ja endog had i deres hjerter. Hold afstand!”. Det var de hårdeste ord, Merkel nogensinde havde udtalt som kansler.

Her optrådte en ligesindet forsamling af mennesker, ikke bare i Dresden, men også i andre øst- og vesttyske byer. Deltagerne pukkede på deres 'identitet' som tyske- re, som demokrater, som kristne. Denne gruppe-identitet var for dem en afgørende indgang til personlig selvforståelse, levevis og tilhørsforhold - et 'imaginært fællesskab', som den nyligt afdøde britiske sociolog Benedict Anderson ville have kaldt det. Samtidig skulle deres 'identitet' adskille dem radikalt fra andre 'identiteter', fra muslimer, og i det hele taget fra alle dem, demonstranterne opfattede som 'fremmede'.

Identitetspolitik er i dag det ufravigelige grundlag for alle national-populistiske partier i Europa. I Norden sidder national-populister i regering i Norge og Finland, mens de har en afgørende og bestemmende politisk indflydelse i Danmark.

I udvalgte lande som Danmark og Frankrig tegner national-populister sig for mellem 25 og 30 procent af stemmerne. I andre lande er tilslutningen mere behersket. Bevægelsen er ikke på 'fremmarch', som det ofte hævdes. Men den har sat sig fast, noterer forfatterne til den seneste større og sammenhængende fremstilling af fænomenet, Jean-Yves Camus og Nicolas Lebourgs Les Droites extrêmes en Europe, der udkom i foråret 2015.

Bogen beskriver detaljeret national-populistiske partiers bestræbelse på at banalisere deres højreradikale arv i takt med partiernes øgede politiske indflydelse. Her er Sverigedemokraterne et kendt eksempel. I Frankrig taler man om, at Marine Le Pens Front National er blevet 'af-diaboliseret'. Det betyder, at det 'djævelske' billede, offentligheden tidligere havde af det højreradikale Front National under Jean-Marie Le Pen, er blegnet som følge af en bevidst omlægning af det politiske udtryk under Marine Le Pen.

De gamle holdninger er der stadig, men det genfødte parti behøver ikke at appel- 


\section{7)}

Identitetspolitik er i dag det ufravigelige grundlag for alle national-populistiske partier i Europa. I Norden sidder national-populister i regering i Norge og Finland, mens de har en afgørende og bestemmende politisk indflydelse i Danmark.

lere til dem. Dets vælgere er trygt forvisset om deres standhaftighed. Tidligere tiders markante anti-semitisme er kategorisk udrenset i partiets offentlige meningstilkendegivelser, men luftes lejlighedsvis ad andre kanaler. Måske med undtagelse af Jobbik i Ungarn bekender alle national-populistiske partier sig til demokrati og retsstat.

Efter talløse tragedier på Middelhavet i løbet af foråret og sommeren traf Merkel en dramatisk beslutning. På sit årlige og altid velbesøgte møde med tyske medier, denne gang den 31. august, påberåbte hun sig den tyske grundlov som grund til, at Tyskland ikke ville se passivt til, mens flygtninge i titusindvis banede sig vej fra lejre omkring Syrien, rendte Schengen-rummets grænser over ende og bevægede sig op gennem Europa.

Merkel lagde det etiske grundlag for den asylpolitik, hun få dage senere blåstemplede, da Tyskland og Østrig i fællesskab besluttede at lade flygtningetoget, der var brudt op fra sine mellemstationer på Balkan og i Ungarn, trække videre nordpå. Hendes beslutning tog Tyskland på sengen. Mens flygtninge overalt i Tyskland blev budt velkommen, lod emsige kilder seriøse tyske medier forstå, at jagten på Merkels efterfølger som kansler var gået ind. Agurketiden var unægtelig forbi.

Merkel nærede selv rygterne. På et pressemøde i Berlin den 15. september med den socialdemokratiske østrigske kansler Werner Faymann, to uger efter deres fælles beslutning om at give syriske flygtninge asylstatus, udbrød Merkel:

"Jeg må ganske ærligt sige: Hvis vi nu begynder at skulle sige undskyld for, at vi i en nødsituation har vist et venligt ansigt, så er det ikke mit land”.

Medierne måbede. Truede kansleren med at smide håndklædet i ringen? Så vi her en Tristanosaurus Rex, eller rettere i hunkønsversionen Tristanosaura Regina, en sørgmodig dinodronning, der går sin egen undergang i møde på abernes planet?

\section{Den tyske grundlovs bud}

Der gik et stille gys gennem Tyskland og store dele af Europa. I opstandelsen var det glemt, at kansleren med sine altid velvalgte ord blot gav sine landsmænd den besked, hun allerede havde givet Europa på det årlige pressemøde den 31 . august, hvor tæppet for det europæiske flygtningedrama gik op i al sin vælde.

Den 31. august sagde Merkel først, at det, der udspiller sig nu i Europa, ikke er en "naturkatastrofe, men en mængde katastrofale situationer. Der udspiller sig uendeligt mange tragedier, og der hersker ufattelig rædsel”. Altså ikke én tragedie, men mængder af katastrofer, uendelig mange. Karavanen af flygtninge fra Syrien bestod af enkelte mennesker, enkelte skæbner, personlige katastrofer.

Kernen i den tyske forfatning er dens humanitet. I første paragraf står, at menneskets værdighed er uantastelig. Merkel læser sætningen sådan, at hvert enkelt menneskes værdighed er uantastelig. Forbundsrepublikkens grundlov blev til som reaktion på Hitler-diktaturet og på andre totalitære diktaturer, hvor enkeltmenneskers skæbne ingen rolle spiller.

"Vi agter hvert enkelt menneskeværd", sagde Merkel som begrundelse for, at 
Tyskland ikke ville overlade flygtningene til deres skæbne. Grundprincippet gælder for hele EU: "De universelle borgerrettigheder har hidtil været tæt forbundet med Europa og dets historie. Det er en af grundimpulserne til den Europæiske Union. Svigter Europa i flygtningespørgsmålet, går denne nære tilknytning til de universelle borgerrettigheder itu. De bliver $ø$ delagt, og det vil ikke være det Europa, som vi forestiller os, og ikke det Europa, hvis grundlæggelsesmyte vi må videreudvikle", sagde Merkel den 31. august.

Her kom sætningen: Uden humanisme vil det ikke være det Europa, vi forestiller os. Ligesom et Tyskland, der ikke kan vise flygtninge et venligt ansigt, ikke er hendes land.

Merkel henviser med rette til præamblen til Lissabon-traktaten, som hun selv underskrev i 2005.

Fællesskabet hviler på Europas kulturelle, religiøse og humanistiske arv. Af den følger de universelle værdier, der tilskrives 'den menneskelige persons' ukrænkelige og umistelige rettigheder i form af frihed, demokrati, lighed og retsstat. Hendes argument hænger sammen.

Humanismen er en fælles arv, der skal videreudvikles og udtrykkes i vores samarbejde. Når Merkel siger: "Det klarer vi", skal vægten lægges på 'vi'. "Vi" er ikke kun tyskerne, det er Europa i fællesskab.

Appellen er rettet til hele Europa.

Den vil næppe lyde så højt i et EU efter Merkel, det er givet. Kun hun har sagt den, og kun hun har trukket følgerne tydeligt op. Det var ingen skåltale. Her trådte en betydelig europæer frem og udfordrede et fremmedhad, som de fleste af hendes kolleger for længst havde bøjet sig for, som var det en selvfølge. Merkel leder, hun følger ikke. Migration til Europa er kommet for at blive. Et meningsmonopol på national afgrænsning over for asylsøgere og indvandring var brudt.

\section{Kamp om overgrænse}

Blandt det ny højres ideologer og fortalere ude i Europa ville forargelsen ingen ende tage. Merkels eksempel blev opfattet som en trussel. National-populister blev for første gang bedt om at legitimere sig med deres argumenter. Deres vælgere så med egne øjne, at det også kunne være anderledes.

Frankrigs Marine Le Pen ilede sine vælgere til undsætning. Merkels motiver var alt andet end ædle, lod hun sine vælgere forstå: "Angela Merkel vil rekruttere lavprisslaver på grund af sit lands demografiske deroute", sagde Le Pen. Samme toner anslår ungarske Viktor Orbans regerende Fidesz-parti. Det vedtog kort før jul en erklæring, hvori det hedder, at Tyskland “importerer billig arbejdskraft". Pascal Bruckner, den franske højreintellektuelle, der er kendt for sin utrættelige kritik af islam, gav på sin side meningsmagere i Paris det argument, de ventede på. Han skrev i en kommentar: "Uden at spørge de små lande i Sydøsteuropa påtvang Merkel dem titusinder af gennemrejsende migranter, i hvilke hun først og fremmest så billig arbejdskraft. Hjerte og forretning, begge indgik i en indbringende form for selvudslettelse".

I november udtrykte Marilynne Robinson, en i USA kendt calvinistisk forfatter, den bagved liggende mekanik bag denne form for selvforsvar og bortforklaringer i en samtale med ingen ringere end præsident Barack Obama i New York Review of Books: "Grundlaget for demokrati er viljen til at tro godt om andre mennesker. Man må forudsætte, at folk grundlæggende ønsker at gøre tingene rigtigt. Men når nogle så begynder at lave sammensvær- 
gelsesteorier og den slags, og får det til at se ud, som om det, der virker godt, i virkeligheden er ondsindet, så godtager de ikke et argument for en holdning, de ikke er enige i”.

Merkel selv redegjorde endnu engang for sin holdning, da hendes parti, CDU, holdt årsmøde i december i Karlsruhe. I sin store tale til de delegerede sagde hun: "I natten mellem 4. og 5. september var tusinder af flygtninge strandet i Budapest. De begav sig til fods ad motorvejen i retning af Østrig. Tyskland og Østrig traf da en beslutning om at lade disse mennesker komme ind i landet. Det var en situation, som stillede vores europæiske værdier på prøve som sjældent før. Jeg siger: Det var intet mere og intet mindre end et humanitært imperativ ... Vi må sikre, at Europa består denne prøve”.

Årsmødet skulle, efter tre måneder uafladelig kamp, være den ultimative konfrontation mellem kansleren og hendes forsamlede tillidsmænd. Her ville det blive afgjort, om Merkel kunne vinde sin første etapesejr. Forud var gået en tvekamp med Horst Seehofer, delstaten Bayerns ministerpræsident $\mathrm{g}$ formand for CSU. CSU er det bayerske søsterparti til Merkels CDU, der er repræsenteret i Forbundsrepublikkens 15 andre delstater.

Seehofer kræver en overgrænse for indtaget af asylsøgende flygtninge i Tyskland. Seehofer havde en særlig moralsk ret til kritik, da hans delstat er flygtningens port til Tyskland. Den ret forspildte han i det tyske flertals øjne, da han senere i september inviterede den ungarske ministerpræsident, Viktor Orban, flygtningenes svorne fjende, til et CSU-møde i Banz-klostret i Bayern. Her frabad Orban sig 'moralsk imperialisme' fra tysk side.

To måneder senere overtog Seehofer selv stafetten. På CSU’s årsmøde i Mün- chen mistede partiformanden besindelsen og rasede i et helt kvarter over kansleren, der endnu ikke havde efterkommet hans ønske om en overgrænse for nye flygtninge. Årsmødets hædersgæst og hyldesttaler, Angela Merkel, stod på podiet klods op ad Seehofer og tog uvejret i stiv arm og med udslukte øjne.

\section{Stor ståhej for ingenting}

Merkel er kvinden med de små skridt. Ikke en eneste gang virkede hun rystet over postyret. Ikke en eneste gang bøjede hun sig og lagde låg på sin kategoriske humanisme. Roland Nelles, en kommentator ved Spiegel Online, spåede allerede i oktober, at Merkel ville sidde sine kritikere ud. Han anførte følgende grunde, som man i landekredsen rundt om Tyskland gør klogt i at bide mærke i.

For det første: Merkel for bliver cool i en krise, når følelserne koger over. Hun er ragende ligeglad med meningsmålinger. For det andet: Der kommer andre emner på bane. For det tredje: Der er intet alternativ til Merkel, det har hun selv sørget for. Og for det fjerde: Koalitionspartneren SPD har ingen interesse i at vælte Merkel. Så går det SPD slet.

Nelles fik ret: CDU's årsmøde i midten af december blev, alle spådomme til trods, en ubeskåret triumf for CDU's kansler. "Fire måneders identitetssønderrivende regeringspolitik endte ikke i nogen nævneværdig tumult, men i knap ti minutters stående bifald til kansleren, altså til den kvinde, hvis kritikere er sikkert forvissede om, at hun selv har lokket mindst halvdelen af flygtningene til landet med sit bydende, evige smil", skrev Bernd Ulrich, ugemagasinet Die Zeits indlandsredaktør, på lederplads efter årsmødet.

Forestillingen om et EU efter Merkel var i december fjernere end i de første kri- 
sedage i september. Men ét er at overbevise en partikongres, et andet at nå ud til vælgerne med budskabet. Om det sker, vil vise sig ved dette års delstatsvalg $\mathrm{i} \mathrm{Ba}$ den-Württemberg, Rheinland-Pfalz, Sachsen-Anhalt, Mecklenburg-Vorpommeren og Berlin. Foreløbig peger meningsmålingerne på, at Alternativ for Tyskland (AfD), ikke vil høste den store gevinst. Partiet når, efter målingerne at dømme, lige præcis at stikke næsen op over spærregrænsen i de tre førstnævnte delstater, nemlig mellem 5 og 7 procent af stemmerne. I de to sidste, Mecklenburg-Vorpommeren og Berlin, kommer AfD ikke ind.

Det tyske efterår lignede stor ståhej for ingenting.

Merkels Tyskland indtager en central rolle i EU, fordi ingen andre medlemslande har vist særlig interesse i lederskab. Landet er blevet en samlende kraft i Europa, en mægler, en forsoner, men også en magt, der vil videre med det europæiske projekt. Traktatændringer har været tabu siden nederlaget ved folkeafstemninger i Frankrig og Holland for den stort anlagte EU-forfatning i 2005. Det er kun muligt at justere gamle, ufærdige konstruktioner, $\mathrm{fx}$ den monetære union og lige nu rejsefriheden inden for Schengen-området. Fejl, som erfaringen har åbenbaret, må rettes.

\section{Hovedmål i Merkels EU}

Hvis vi specielt fokuserer på Merkels EU - og dermed det EU, den tyske kansler er med til at holde sammen - var overskrifterne i hendes lange tale på CDU's årsmøde i december: En europæisk fredsordning (fokus på Ukraine og Rusland). En styrket valutaunion (fokus på euro og statsfinanser). Energirevolution (fokus på vedvarende energi, væk fra atomkraft). Et $\mathrm{EU}$, rustet til politisk at takle en ekspansiv globalisering (fokus på åbenhed og chancer). Europæisk solidaritet (fokus på det, der forener Europa). Europæisk sikkerhed (fokus på terror og dårlig integration). $\mathrm{Og}$ Europas humanitære eksistensberettigelse.

Hovedrollerne i hendes tale indtog de tre politiske institutioner Tyskland, Europa, Frankrig og dermed kombinationen Frankrig-Tyskland (i runde tal blev disse institutioner nævnt ca. 65, 55, 20 og 5 gange). Tysklands prominente placering skyldes ikke selvovervurdering, men det faktum, at Merkel talte til tyske politikere, der skal styre Tyskland. Men hvilke andre europæiske stats- eller regeringsledere ville bruge så meget af deres taletid på at fremhæve europæiske mål? Og Frankrig: Merkel sagde igen og igen, at Tyskland står ved Frankrigs side. Denne akse i EU-samarbejdet er urokkelig.

De fleste af disse mål overlever Merkels afgang, hvornår den så måtte komme. De er tysk statsræson. Men ved temaet flygtninge sætter hun suverænt og alene sit mærke ved at fremhæve, hvad der giver fællesskabet mening og retning. Hendes overordentlige kampkraft i det tyske efterår viser til overflod, at kansleren finder denne værdi uundværlig i en tid, hvor principløse ledere vender og drejer sig som feberpatienter, der ikke kan finde hvile i deres lagner.

Flygtningekrisen har vist, at der er plads til forbedringer i Europa - helt uden traktatændringer. Den italienske politiker og tidligere EU-kommissær Emma Bonino udtalte i december: "Europas såkaldte flygtningekrise skulle aldrig være blevet et nødstilfælde. At finde plads til en million asylsøgere kan ikke være en stor udfordring for EU - et område med 500 millioner borgere, som hvert år byder tre millioner immigranter velkommen. Manglen på et samordnet svar forvandle- 
I deres værste skikkelser ser nationalisme og religiøs fanatisme samfundskonflikter med samme identitets-ideologiske briller. Merkel advarer Europa mod at gå i den retning. Identitetspolitik skærрer de spændinger, der рræger en globaliseret verden. Vi kommer kun videre fredeligt, hvis vi afstår fra identitetspolitik og fastholder respekten for det enkelte menneskes værd, som det sker i den tyske forfatning og Lissabon-traktaten.

de ulykkeligvis et håndterbart problem til en akut politisk krise - en krise, der - som den tyske kansler Angela Merkel rigtigt har advaret imod - kan ødelægge EU”.

Merkels udspil i flygtningekrisen var en klar reaktion på den identitetspolitik, der giver EU stadig mere slagside. Hvis man gør sig den umage at læse, hvad hun - den ene gang efter den anden - udtrykker, er budskabet enkelt at afkode. Merkel levede sine første 39 år i DDR, et kommunistisk diktatur. Her lærte hun marxistisk identitetspolitik at kende indefra. Den lærer os, at en række modsætninger i klassesamfundet er uovervindelige og uforsonlige. Kun kamp, ikke kompromis kan bringe samfundet videre. Kun én klasse, arbejderklassen, har ved sin identitet fremtiden for sig.

I deres værste skikkelser ser nationalisme og religiøs fanatisme samfundskon- flikter med samme identitets-ideologiske briller. Merkel advarer Europa mod at gå i den retning. Identitetspolitik skærper de spændinger, der præger en globaliseret verden. Vi kommer kun videre fredeligt, hvis vi afstår fra identitetspolitik og fastholder respekten for det enkelte menneskes værd, som det sker i den tyske forfatning og Lissabon-traktaten.

EU efter Merkel er et EU, som vi på nuværende tidspunkt må se frem til med bekymring, hvis vi anser et velfungerende europæisk fællesskab for et værdifuldt redskab til at forme fremtiden efter vores nationale og overnationale interesser. Et EU, hvor Merkel er tvunget væk i utide, gør det ikke nemmere for gratister at køre med på trinbrættet, mens de, der tør, sætter retningen. 